\title{
Early Mercian Text Production: Authors, Dialects, and Reputations
}

\begin{abstract}
There are suggestions that King Alfred's legendary literary renaissance may have been a reaction to the efforts of the neighbouring kingdom of Mercia. According to Asser, Alfred assembled a group of literary scholars from this rival Mercian tradition at his court. But it is not clear what early literary activities these scholars could have been involved in to justify their pre-Alfredian reputation. This article tries to outline the historical and literary evidence for early Mercian text production, and the importance of this 'other' early literary corpus. What is our current knowledge of Mercian text production and the political and literary relationship of Mercia with Canterbury? What was the relationship of Alfred's educational movement with its Mercian forerunner? Why is modern scholarship better informed about Alfred's movement than any Mercian rival culture? If our current knowledge of this area is insufficient for the writing of a literary history of Mercia, a provisional list of texts and bibliography, published electronically for convenient updating, may prove useful in the meantime.
\end{abstract}

\section{Alfredian evidence for Mercian literary culture}

That King Alfred claims to have initiated an educational Renaissance is well known. Alfredian writings acknowledge a marked decline in learning and scholarship, at least in terms of Latin text composition and manuscript production, and at least in Wessex (Lapidge 1996, 436-439). But the same texts also suggest the existence of a rival Mercian culture of literary competence, preceding Alfred's reform. The extent of such a Mercian tradition remains largely uncertain. A seminal study published more than half a century ago by Rudolf Vleeskruyer included a long and relatively comprehensive list of texts containing (in Vleeskruyer's opinion) Mercian features, with some commentators suggesting that this list overstated its evidence. ${ }^{1}$ As the discussion below will show, more recent assessments have tended to be more comfortable again with the idea regarding a substantive Mercian culture of literary production. First, however, it will be necessary to reexamine the cultural contact between the Mercian and West Saxon literary corpora of texts. What evidence is there in Alfredian writings for Mercian scholarship and what is the relationship between this scholarship and its West Saxon successor?

In his Vita Alfredi composed in 893, Bishop Asser of Sherborne explains

\footnotetext{
${ }^{1}$ Vleeskruyer1953, with the list of texts at 51-62, and some features assumed to be Mercian by Vleeskruyer listed at 42 note 4 . These include, for example, phonological features such as retraction of short $æ$ to short $a$ before I + consonant, short $o$ for West Germanic short $a$ before nasal, long close $e$ for West Germanic long $a$, -nis for West Saxon -nes, and morpho-syntactical feastures such as mid with accusative. Reactions to Vleeskruyer's survey will be discussed below.
} 
how the foreign scholars Werferth, Plegmund, Werwulf, AEthelstan, Grimbald and John came to be at the court of King Alfred:

At tunc Deus quaedam solatia regiae benevolentiae (...) veluti quaedam luminaria transmisit Werfrithum, scilicet Wigernensis ecclesiae episcopum, in divina scilicet scriptura bene eruditum qui, imperio regis, libros Dialogorum Gregorii papae et Petri sui discipuli de Latinitate primus in Saxonicam linguam, aliquando sensum ex sensu ponens, elucabratim et elegantissime interpretatus est; deinde Plegmundum, Mercium genere (....) venerabilem scilicet virum, sapientia praeditum; Æthelstan quoque et Werwulfum, sacerdotes et capellanos, Mercios genere, eruditos. Quos quatuor $\mathbb{E}$ Elfred rex de Mercia ad se advocaverat (...) advocavit Grimbaldum (...) omni modo ecclesiasticis disciplinis et in divina scriptura eruditissimum (...) lohannem quoque... in omnibus disciplinis literatoriae artis eruditissimum. ${ }^{2}$

Three of the scholars, Plegmund, Werwulf, Athelstan, are designated as Mercians "by birth" ("Mercius genere"), whereas Werferth is at least attributed a Mercian area of professional activity. ${ }^{3}$ One important question is what Asser may have regarded as Mercian: theoretically this could have included ethnic criteria, perhaps overlapping with differences in linguistic dialect, in the sense that linguistic features which can now be identified as characteristically Mercian may have been identifiable as such also in early medieval times. Since Asser was Welsh and not a native speaker of Old English, however, one wonders to what extent his designation of anyone as Mercian could have relied on linguistic features. Asser may in any case have associated any ethnic or linguistic criteria with the great religious houses and ecclesiastical centres of Mercia, such as Worcester, Hereford, Lichfield and Leicester which must have been known to him specifically as (politically) Mercian centres. It is perhaps more likely that geographical or political criteria were on Asser's mind, rather than membership of a linguistic area, especially because the former were not totally coterminous with the area of Mercian dialect. Canterbury and London could in the ninth century certainly be regarded as centres of Mercian literary culture and political influence, without being areas where the use of Mercian dialect forms was endemic in a local

\footnotetext{
${ }^{2}$ Stevenson 1904, 62-63. "At that point God (...) sent some comforts for this royal intention certain luminaries, as it were: Werferth, the bishop of Worcester, a man thoroughly learned in holy writings who at the king's command translated for the first time the Dialogues between Pope Gregory and his disciple Peter from Latin into the English language, sometimes rendering sense for sense, translating intelligently and in a very polished style; then Plegmund (...) a Mercian by birth and an estimable man richly endowed with learning; and also Æthelstan and Werwulf, both priests and chaplains, Mercians by birth and learned men. King Alfred summoned these four men to him from Mercia (...) He summoned Grimbald, (...) extremely learned in every kind of ecclesiastical doctrine and in the Holy Scriptures... Similarly he summoned John, (...) immensely learned in all fields of literary endeavour", translation from Keynes and Lapidge 1983, 92-93.

${ }^{3}$ For commentary, see Stevenson 1904, 303-12; Keynes and Lapidge 1983, 259-260.
} 
population. ${ }^{4}$ It is interesting that Asser makes the distinction between three scholars who seem to be Mercian in a more native way than the fourth seems to have been, which does imply some knowledge of the unstable political realities or the biographies of the four men involved. Another question is how reliable Asser's idea of what constitutes Mercian origin may have been. In any case, his account seems to be more interested in doing justice to West Saxon achievements rather than Mercian ones, for example, when he emphasises the joint driving forces behind this recruitment: the scholars were sent by God ('Deus...transmisit'), but also summoned by Alfred ("Flfred ... advocaverat"). Regarding the question as to what the recruited scholars could already have achieved to highlight themselves for recruitment by Alfred, Asser makes careful distinctions between Werferth as the most learned ("in divina scilicet scriptura bene eruditum", namely learned in holy writings), Plegmund ("sapientia praeditum", endowed with wisdom), and Werwulf and Æthelstan ("eruditos", learned men). Even allowing for elegant variation, the gradation of learning between these men presents a clear hierarchy, made even more explicit by awarding the highest level of erudition to the nonMercian foreigners Grimbald ("omni modo ecclesiasticis disciplinis et in divina scriptura eruditissimum", extremely learned in every kind of ecclesiastical doctrine and in the Holy Scriptures) and John ("in omnibus disciplinis literatoriae artis eruditissimum", immensely learned in all fields of literary endeavour). Only these two foreigners could display learning of a superlative type.

Asser's account suggests that the king's learning efforts also seem to have gone from comparative to superlative: Asser had described Alfred's hunger for knowledge as initially satisfied by the Mercian staff, only for further interest to arise subsequently, when only the importation of overseas personnel would be good enough for the king: "Quorum omnium doctrina et sapientia regis indesinenter desiderium crescebat et implebatur (...) Sed, cum adhuc nec in hoc quoque regalis avaritia, sed tamen laudabilis, grata esset, legatos ultra mare ad Galliam magistros acquirere direxit". ${ }^{5}$ If Alfred's head-hunting did take place in two stages, such an evolving process could also point to changing ambitions in the king: Asser's account suggests that the Mercian recruits were to function as personal tutors to the king, but makes no mention of a greater ambition involving nationwide educational reform. In sum, Asser's hierarchy of learning seems to equate Wessex with unlearnedness, Mercia with a passable amount of homegrown erudition, and territories overseas with the highest levels of education, an

${ }^{4}$ Godden 2012, 132-139; Keynes 2015, 28-29. For the political background, see Keynes 1998, esp. 12-21, and Keynes 2001.

${ }^{5}$ Stevenson 1904, 62-63. "[T] he king's desire for knowledge increased steadily and was satisfied by the learning and wisdom of all four [Mercian] men (...) However, since the royal greed (which was entirely praiseworthy!) in this respect was not yet satisfied, he sent messengers across the sea to Gaul to seek instructors". 
education that spans various literary genres. It is difficult to ignore, of course, that the Welshman Asser himself belongs to a similar international category. ${ }^{6}$

Asser unfortunately mentions no literary genres in which Mercian scholars may have excelled before joining him, and there is in any case no mention of the four named men having authored any writings of their own before being headhunted by Alfred. Attempts to link the four to any surviving anonymous Mercian literary productions with which they may have been involved depend on the chronology of their careers. The four are barely mentioned in documentation before they followed Alfred's call c. 885-886.7 Subsequent to their Alfredian encounter, all of them, however, remain documented in the last decade of the ninth and some years into the tenth century. Werwulf and $\mathbb{E}$ thelstan are thought to have attested a number of charters in the $890 \mathrm{~s}$, with Athelstan possibly appointed bishop of Ramsbury in c. 909. ${ }^{8}$ The trace of Werferth, bishop of Worcester from c. 872 to c. 915 , can be followed for a similar period; ${ }^{9}$ Plegmund, appointed archbishop of Canterbury by Alfred in 890, is attested as bureaucratically active until the 920s, deceased in $923 .{ }^{10}$ In terms of their documentation at least in surviving documents, Alfred's call to Wessex seems to have been a major event, if not the major event, in their lives.

If we assume a potential maximum of some fifty years of literary activity, the scholarly careers of these men could really only have begun in the second half of the ninth century, without reaching back very far into the first half of that century. This, as will become clear below, does probably not allow them to be associated with the composition of the better known surviving Mercian productions of the earlier ninth century such as the Vespasian Psalter glosses or the Blickling Psalter glosses. ${ }^{11}$ But if it seems uncertain whether Alfred's four helpers with a Mercian connection were the authors of such texts, they may in any case have been involved in the transmission and reading of this gloss material. The next question has to be whether the four men could have authored Mercian texts for which no precise date of composition has been established, and which could theoretically have been composed in the second half of the ninth century, such as

\footnotetext{
${ }^{6} O D N B$, s. v. 'Asser'.

${ }^{7}$ Godden 2012, 134. "It is not known when these men joined the king, nor indeed whether they did so at one and the same time"; Keynes and Lapidge 1983, 26. Stevenson 1904, 303-304, suggests an earlier arrival date for Werferth than for Plegmund.

${ }^{8}$ Keynes and Lapidge 1983, 259; Stevenson 1904, 304-305. PASE, s. vv. 'EEthelstan 4', 'Wærwulf 6'. The common nature of the two names complicated the identification of these individuals.

9 Jayatilaka 2014, 489; ODNB, s. v. 'Werferth'; Keynes and Lapidge 1983, 259; Stevenson 1904, 303304; PASE, s. v. 'Wærfrith 6'.

${ }^{10}$ Keynes 2014; Keynes and Lapidge 1983, 259; ODNB, s. v. 'Plegemund'; Brooks 1984, 152-154, 170-174, 209-214; Stevenson 1904, 303-304; PASE, s. v. 'Plegmund 1'.

${ }^{11}$ For texts and dates of composition, see the details given in note 35 below.
} 
the Old English Martyrology. ${ }^{12}$ Authorship of one of the longer surviving texts would certainly have made the men interesting to Alfred, whether his project was one of finding a personal tutor or one requiring an adviser for a larger translation project. Answering this question is made difficult by the fact that it remains unclear whether the cultural slump lamented by Alfred also affected Mercia, and if so, to what extent (Lapidge 1996, 436-438).

Any attempt to establish the qualifications of Alfred's visiting scholars is made difficult by a further complication. Asser's account describing Alfred's efforts to surround himself with learned foreign scholars was probably influenced by a literary precedent, namely the description of a similar group of scholars at the court of Charlemagne, contained in Einhard's Life of Charlemagne. ${ }^{13}$ The potential use of a literary model seems to cast the greatest doubt on the factual reliability of Asser's account. But even if we allow a degree of fictitiousness in Asser's famous statement, his account is interesting in that it does acknowledge Mercian quality, and relative literary superiority in comparison with Wessex, unfortunately doing so without providing much detail on the nature of such Mercian learning. Given the poor state of West Saxon learning, a Mercian tradition could theoretically have been quite dismal itself and still relatively superior to West Saxon efforts. At worst, Asser's account demonstrates his own (if not Alfred's) suspicion that non-West Saxon scholars should be seen as superior to West Saxon ones, and that Mercia was the first and most obvious source where such superior scholars could be found.

The same sense of Mercian superiority also emerges from a further Alfredian text which comments on the matter. The Preface to the Old English translation of Gregory's Cura pastoralis confirms that Alfred received help with reading Latin and translation into the vernacular, with the area south of the Humber and north of the Thames being outlined as the origin from which this help came. ${ }^{14}$

ða ongan ic (...) đa boc [i.e. the Pastoral Care] wendan on Englisc, hwilum word be worde, hwilum andgit of andgiete, swæ swæ ic hie geliornode æt Plegmunde minum ærcebiscepe, ond æt Assere minum biscepe, ond æt Grimbold minum mæsseprioste, ond

\footnotetext{
${ }^{12}$ For Plegmund as a possible author, see Sisam 1953, 217; Bately 1988, 103. The text uses very recent source materials from Saint-Bertin, which could point to a connection with Grimbald; see Rauer 2013, 2. But see also the more sceptical remarks by Rauer 2013, 12-13.

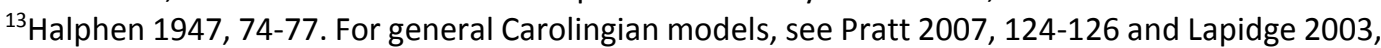
28. For discussion, see Godden 2012, 137-139. Godden points out that Asser does not borrow the idea that the king is recruiting for a nationwide cultural Renaissance. But the reason for this omission may lie in the fact that reference to such a larger programme would show insular personnel like Asser himself in an inferior light.

${ }^{14}$ Gretsch 2000, 104; Irvine 2013, 212; Gneuss 1972, 66-68.
} 
æt lohanne minum mæssepreoste. ${ }^{15}$

Like Asser's account, this preface also leaves it unclear whether the four Mercian helpers had authored written texts themselves; both accounts, however, suggest expertise in translation at least, and perhaps also the teaching of Latin and translation. The concept of translation also seems to be a wide spectrum of literary activity. On the one hand this could involve just the ad-hoc oral translation of a written Latin text, without any noting down of the translation for further circulation, or, in the middle of the spectrum, the compilation of written glosses as a translation tool for oneself or others, or, at the far end of the spectrum, the production of a polished written translation as a text of its own, for further transmission. It is unclear, for example, which scenario applies in the case of the famous anecdote regarding Bede's deathbed translation of the Gospel of St John, often cited as the beginning of Old English prose (Ross 1969, 493-4; Liuzza 2001, 233). In that sense it is possible that the Mercian helpers were above all experienced simply in reading and making sense of earlier Latin texts circulating in Mercia (Bately 1988, 105). But even if they were just readers of Latin and no more, that in itself may have been enough to qualify them to tutor an illiterate king picking up the basics of Latin.

It is also interesting that, in this second account, the two more junior Mercians, Werwulf and $/ E$ thelstan, described as priests and chaplains by Asser, do not feature at all. This silence could be related to their lack of eminent ecclesiastical office, as all other persons named are identified in connection with Alfred's senior ecclesiastical positions. The silence about Werwulf and Æthelstan could on the other hand also be linked to their general juniority, already acknowledged in Asser's text.

In sum, there are historical indications, then, which acknowledge preAlfredian Mercian literary renown, even if this is done more or less grudgingly and with an implicit comparison against overseas competition. The non-Mercian origin of these views perhaps make them less direct, but nevertheless all the more plausible.

\section{Modern notions of a Mercian literary corpus}

The question of a possible pre-Alfredian Mercian corpus of materials has occupied literary historians for many years, and seems to have been mainly driven by the growing knowledge of Old English dialectology. ${ }^{16}$ Most prominently, Rudolf

\footnotetext{
${ }^{15}$ Mitchell and Robinson 2012, 215. "Then I began to translate the book into English, sometimes word for word, sometimes more idiomatically, just as I had learned it from Plegmund my archbishop, and Asser my bishop, and Grimbald my masspriest, and John my masspriest". For background, see Irvine 2015, 153-160.

${ }^{16}$ 'Mercian' as an Old English dialect term seems to be attested from 1836; OED, s. v. 'Mercian, $n$.
} 
Vleeskruyer had optimistically spoken of a pre-Alfredian 'tradition of English prose-writing' which he explored in his new edition of the Old English St Chad. ${ }^{17}$ Early reviewers of Vleeskruyer's work were not markedly critical of his attempted contextualisation of St Chad in what he saw as a Mercian corpus of texts, and of which he attempted to compile an inventory. ${ }^{18}$ The most probing questions regarding Vleeskruyer's draft list of early Mercian texts were later raised by Janet Bately, in a survey particularly focused on prose, more specifically what she termed "literary" prose. ${ }^{19}$ But in defence of Vleeskruyer's efforts, it needs to be pointed out that Vleeskruyer was not exclusively interested in what Bately terms "prose", but more inclusively all literary production, since the production of glosses and glossaries, for example, is arguably also evidence of literary activity. ${ }^{20}$ Vleeskruyer's list importantly includes all genres, prose, poetry, literary, nonliterary writings, glosses and glossaries, and charters. Bately is also very specific in her interest in the identification of what can "safely" or "with any certainty" be attributed to a particular dialect or date. ${ }^{21}$ But most commentators would probably agree that few Anglo-Saxon texts can be dated safely, and that a text's anonymity is an obvious and unavoidable complication. It would be fair to say that Vleeskruyer's criteria in what could be included as 'Mercian', 'tradition', or 'literature' are relatively elastic, and in any case more elastic than Bately's, leading to a relatively inclusive and optimistic survey of Mercian texts, but its reputation as a complete misrepresentation of Mercian literary survivals seems undeserved. 22

That Vleeskruyer's initial survey had got it broadly right is also suggested by the subsequent survey undertaken by Franz Wenisch, which had a wider remit in dialectological terms (including texts with Anglian rather than Mercian features), but also had a narrower focus in its linguistic features, focusing on vocabulary alone. Wenisch's survey managed to include some forty prose texts of

\footnotetext{
and adj.'; Garnett 1836. I am currently preparing a more detailed historical study of early Mercian dialectology.

${ }^{17}$ Vleeskruyer 1953, 51-61, quotation at 61. This author is sometimes (and equally correctly) cited as Vleeskruijer.

${ }^{18}$ See Campbell 1955b; Sisam 1955; Woolf 1955; Brunner 1956b; Stanley 1957. More critical of Vleeskruyer's list of texts containing Mercian features are Campbell 1955a and Wilson 1959, 293.

${ }^{19}$ Bately 1988, 114, 118; see also Liuzza 2001, 235, "the growth and development of Old English prose began in earnest, however, in the last decade of the ninth century, with the educational initiatives of Alfred the Great"; Alexander 1983, 132, "Old English prose, by contrast, was called into being by a decision of Alfred".

${ }^{20}$ See the categories of Old English in Frank and Cameron 1973, 26, with Bately evidently focusing on category $\mathrm{B}$, and Vleeskruyer including all categories in his survey.

${ }^{21}$ Bately 1988, 118; see also Irvine 2013, 209-231, at 21; Vleeskruyer 1953, 50 "texts that may justifiably be considered purely or basically Mercian". It is ironic that more recently even the dating of Alfredian texts has increasingly become unsafe; see Godden 2007 and Godden 2013.

${ }^{22}$ For good summaries of current views, see Fulk 2008, 81-82; Fulk 2012, 64-65.
} 
presumed or probable Mercian origin on the basis of vocabulary alone. ${ }^{23}$ But all commentators would probably agree that although vocabulary is an important indicator of a possible Anglian or Mercian origin of a text, it is not the only one. Characteristic dialectal features in terms of phonology, morphology, orthography, and syntax, also have a role to play. Anglian or Mercian characteristics from these various linguistic fields have particularly been collected for studies or editions of individual texts (rather than an entire corpus of texts), no doubt for practical reasons, for example by Günter Kotzor, in the case of the Old English Martyrology, a text whose Mercian features have been studied in great detail. ${ }^{24}$ The range of such texts whose Mercian or Anglian features have recently been surveyed also includes Beowulf, the Old English Canons of Theodore, the Old English translation of Gregory's Cura pastoralis and a range of anonymous homilies. ${ }^{25}$ Reference grammars tend to give basic lists of Anglian (or non-West-Saxon, or Mercian) dialect features across a group of texts containing them. ${ }^{26}$ Finally, Anglian (or Mercian) features are also covered in a range of other, less systematic surveys of Old English dialectology. ${ }^{27}$

One major problem in the discussion of Mercian dialectology is its relatively indistinct nature, in terms of its diachronic development, synchronic variety, and particularly in its geographical spread: "Mercian is the least well defined of the Old English dialect areas." 28 It is this blurred dialect outline and its common definition by what it is not (especially the fact that it is not West Saxon, not Nurthumbrian and not Kentish) which has led to sceptical reactions, as exemplified by Bately's response to the work of Vleeskruyer witnessed above, or the more recent reactions to the sociolinguistic contextualisation of Mercian features by Thomas Toon (summarised in Hebda 2014, 242-244). Its elusive

\footnotetext{
${ }^{23}$ Wenisch 1979, list of texts 19-82, dialectological classification 325-328.

${ }^{24}$ Kotzor 1981, I, 327-405, with 325-366 on Anglian vocabulary, 367-370 on syntactical features characteristic of Anglian dialect, 371-386 on morphological features and 387-392 on phonology and orthography.

${ }^{25}$ Fulk, Bjork and Niles 2008, clvii-clviii, covering lexical, syntactical, morphological and phonological features; Fulk and Jurasinski 2012, xxviii-xxxv, phonology, orthography, morphology, syntax and vocabulary; Schreiber 2003, 1-31, at 10-17, including phonology, morphology, lexis; Fulk 2008, 81100 , at 86-88, surveying phonological, morphological, syntactical and lexical features.

${ }^{26}$ Brunner 1965, 8-11, with basic phonological and morphological characteristics at 10-11, and a list of texts at 8-10; Campbell 1959, 5-8 list of texts; Hogg 2011, 5-7 list of texts; Nielsen 1998, 92-93 list of texts, 95-99 briefly on Old English dialect criteria; Jordan 1906, lexical survey; Hofstetter 1987, 21-22, phonology and morphology.

${ }^{27}$ Common Old English dialect features, including Anglian or Mercian ones, are also covered in Toon 1992, 430-431. See also Lass 1994, 170-171 on the verb 'to be'; Dresher 1980 on Mercian second fronting; Schabram 1965, on Old English dialect words for superbia; Mitchell 1985, passim on Anglian syntactical and lexical features, e.g. $\S 440$ use of nænig; §§104-112, combination of possessive and demonstrative.

${ }^{28}$ Hogg 2011, 5. See also Nielsen 1985, 223-252; Hogg 1985a, and Gneuss 2013, 41.
} 
geographical range has led commentators to posit a literary language of Mercian, that is, a dialect not linked to geographical origin or ethnicity, but associated with certain educational (often orthographical) standards in a centre of literary production, and affecting scribal orthography (Fulk 2012, 63-74; Hogg 1985b, 183203). Particularly Canterbury has been highlighted as such a centre of literary activity with a complex dialectal environment, with a possible local literary language or 'Mercian-Kentish church language', as some have suggested. ${ }^{29}$ 'Mercian literature', containing Mercian dialect features, could thus very well include texts written not by a Mercian and not in Mercia. ${ }^{30}$

The dialectological complexity of Mercian language is matched by the difficulties one faces in the distinction of paleographical and codicological criteria for Mercian book production: "the elusive nature of a Mercian 'identity' is reflected in the hesitancy and dispute which pervade discussions concerning the attribution of manuscripts of its monastic scriptoria". ${ }^{31}$ As Michelle Brown's example of the Tiberius group of manuscripts has demonstrated, it is again Canterbury with its supra-regional characteristics which complicates the picture. ${ }^{32}$

If it has so far proved difficult to write the literary history of Mercia, one tool which should prove useful in these discussions of literary production, dialectology and paleography is an updatable register of texts and books associated with Mercian origins. ${ }^{33} \mathrm{I}$ am proposing to present such an electronic register, in the hope that such a survey can amount to being more than just an Electronic Vleeskruyer. As a first priority, it is hoped that the register can give details of a text's or manuscript's various characteristics in terms of dialectology (vocabulary, syntax, phonology, morphology, orthography), paleography, and literary history. ${ }^{34}$ The listings will also aim to identify texts unambiguously, because titles, short titles, edition details and reference numbers have developed

\footnotetext{
${ }^{29}$ The suggestion was first made by Wildhagen 1913, 437. See also Gneuss 1972, 82; Seebold 1993, esp. 273-277; Toon 1983, 197-214; Rauer 2016, 78; Rauer 2013, 6; Toon 1992, 427 and 450-451; Lowe 2001, 76. For other forms of standardised Old English, such as the famous 'Winchester vocabulary' and 'Winchester usage', see Gretsch 2013, 290-291.

${ }^{30}$ For Anglian features in early West Saxon texts, see also Gretsch 2000, 98-106 and 120-121. The fact that Anglian features can be found even in texts authored by Ælfric demonstrates the difficulty of the dialectological situation, Godden 1980, 222-223.

${ }^{31}$ Brown 2001, 279-290, at 279. For the earlier background of this discussion, see Kuhn 1957.

${ }^{32}$ Brown 2001, 280, highlights the "magnet principle of manuscripts attribution in which one known centre attracts otherwise unattributed 'floating' works, by default. In rectifying such tendencies the pendulum often initially swings too far in the other direction"; see also Rauer 2013, 13 on the tempting but unhelpful attributions of texts to Canterbury.

${ }^{33}$ The multi-disciplinary collection of studies of Brown and Farr 2001 includes only one contribution with a particular focus on Mercian literary production, namely that of a single hagiographical tradition (Guthlac), Roberts 2001. More wide-ranging is the comparative study by Wragg, forthcoming.

${ }^{34}$ http://www.st-andrews.ac.uk/ cr30/Early Mercian Literature
} 
considerably since the compilation of the lists by Vleeskruyer and Wenisch. As with previous surveys of this type, being inclusive will be of advantage. A further aim of this survey will be to act as a bibliographical tool, with a focus on the secondary literature pertaining to Mercian language and text and book production. It is to be hoped that tools of this type can help systematise the available modern evidence for early Mercian literary activity.

\section{Features of a Mercian Corpus of Texts}

One of the most interesting insights one would eventually hope to gain from a register of Mercian texts or books would be a better idea of the extent of this corpus. Another aim will be to distinguish particular patterns which could be characteristic of an early Mercian production. In this regard, and bearing in mind the preliminary nature of this survey, four patterns in particular should be highlighted here which will be of interest for further research:

1) Glosses and glossaries. Among the earliest Mercian texts are several famous gloss collections and glossaries, probably testifying to a conscious and distinctive Southumbrian tradition of gloss production and usage of glosses: the Épinal Glossary (seventh century), Glosses on the Blickling Psalter (eighth century), the Corpus Glossary (early ninth century), the Vespasian Psalter interlinear glosses (ninth century), to name just some of the better known early examples. ${ }^{35}$

2) Arising from a tradition of gloss production and gloss usage, an authorial predilection for a relatively literal translation style. There seems to be a suggestion that several of the long texts, such as the Old English translation of Bede's Historia ecclesiastica and the Old English Martyrology may even incorporate, or to some extent have grown out of, glossed source material. ${ }^{36}$ It is hard not to see a particularly literal translation style as a natural consequence of a habitual dependence on glosses and glossaries as translation tools. Commentators have, however, tended to disagree on the specifically Mercian nature of such a technique (Stanton 2002, 58; Bately 1988, 132-138).

3) The production of vernacular hagiography, and the question whether vernacular hagiography was intended for a different audience compared with Latin hagiography. Several early Mercian texts are examples of early vernacular hagiography, translated (often very literally) from Latin sources: the Old English Martyrology, the Old English translation of Bede's Historia ecclesiastica, the Old English translation of Gregory's Dialogi, and St Chad. The probable association of a rare ninth-century Latin legendary with Canterbury, Paris Bibliothèque national de France, lat. 10861, also testifies to an interest in hagiography in this environment (Brown 1986).

\footnotetext{
${ }^{35}$ For some patterns in Southumbrian gloss production, see Rusche 2016, 64-76. For early Psalter glosses, see e.g., Toswell 2014, 223, 250-251 and 398-400, and Gretsch 2013, 280-281.

${ }^{36}$ Irvine 2013, 212; Stanton 2002, 58; Waite 2014, 8-11; Rauer 2016, 79-80; Rusche forthcoming.
} 
4) The possible grouping of texts within a Mercian corpus, related to production centres. For example, Elmar Seebold has outlined shared characteristics of a group of South Mercian texts, possibly with an origin in Kent, and particularly Canterbury (Seebold 1993). According to Seebold, this group could most obviously include Werferth's translation of Gregory's Dialogi; other texts most plausibly associated with this group include the anonymous Capitula Theodulfi, and the Old English Life of Saint Mary of Egypt (Seebold 1993, 273-277).

It would seem that, with current estimates, early Mercian literary production was indeed fairly extensive, particularly if not just lexical, but also other, criteria are applied in the identification of texts, together with codicological and historical circumstantial evidence. The early Mercian texts that are represented in the corpus cover several literary categories, including glossaries, interlinear glosses, prose and poetry, and thus a range of literary text types which seems to be more diverse than that of any Alfredian project. The Mercian tradition seems to have been so extensive that some modern commentators have distinguished several separate production strands within it, arising from several centres of production. There seems to be no reason for assuming that this Mercian tradition had come to a neat hiatus when Alfred issued his invitation to a number of Mercian scholars. (Asser's assertion that Werferth began his translation of Gregory's Dialogi at Alfred's instigation in particular could be questioned). There can in any case be no doubt that some parts of a Mercian tradition were in the tenth century West-Saxonised, for example, on a dialectal level. ${ }^{37}$ The question arises at what point the absorption of Mercian texts into West Saxon literature may have started, and in what terms.

Recent scholarship has increasingly cast doubt on Alfred's personal input in the literary productions so far attributed to him, wholly or partially. The opus ascribed to his person seems to be shrinking, with Alfredian apocrypha (as they have recently been called) now outnumbering Alfredian texts. ${ }^{38}$ It is ironic that the same fate now seems to be threatening the Alfredian canon that had earlier befallen Vleeskruyers's initially proposed corpus of 'West Mercian' texts. If Alfred's personal role as the architect of early Old English prose is diminished in such arguments, the question arises as to what extent the educational Renaissance of the ninth century could still be regarded as an 'Alfredian' project. Sharon Rowley has rightly asked: "What questions or possibilities do we eliminate if we envision all surviving Old English prose as part of a highly centralized program enjoined by Alfred or his successors" (Rowley 2011, 45)? One such question and possibility which must not be eliminated is the idea that an Alfredian Renaissance could have been a reaction to Mercian efforts as much as a response to cultural

\footnotetext{
${ }^{37}$ Kotzor 1981, I, 403-404; Yerkes 1982, 9-11; Sisam 1953, 216-217; Gretsch 2013, 288-289.

38Johnson 2015, 368-395; see also the general remarks by Godden 2013, 91-110, Godden 2007 and Gretsch 2013, 281-287.
} 
neglect in Wessex and the foreign threats it faced. ${ }^{39}$

\section{Bibliography}

Alexander 1983: M. Alexander, Old English Literature, London.

Bately 1988: J. M. Bately, "Old English Prose before and during the Reign of Alfred", in: Anglo-Saxon England 17 1988: 93-138.

Brooks 1984: N. Brooks, The Early History of the Church of Canterbury, Leicester.

Brown 1986: M. Brown, "Paris, Bibliothèque National, lat. 10861 and the Scriptorium of Christ Church, Canterbury", in: Anglo-Saxon England 15: 119-137.

Brown 2001: M. P. Brown, "Mercian Manuscripts? The 'Tiberius' Group and Its Historical Context," in: Mercia: An Anglo-Saxon Kingdom in Europe, ed. J. P. Brown and C. A. Farr, London, 279-290.

Brown and Farr 2001: Mercia: An Anglo-Saxon Kingdom in Europe, London.

Brunner 1956b: K. Brunner, Review of Vleeskruyer, The Life of St. Chad, in: Anglia 73: 371-376.

- 1965: K. Brunner, Altenglische Grammatik, 3rd edn, Tübingen.

Campbell 1955a: A. Campbell, Review of Vleeskruyer, The Life of St. Chad, in: Medium AEvum 24: 52-56.

- 1959: A. Campbell, Old English Grammar, Oxford.

- 1967: A. Campbell, "The Glosses," in: The Vespasian Psalter, ed. D. H. Wright, Early English Manuscripts in Microfiche Facsimile 14, Copenhagen, 81-92.

Campbell 1955b: J. J. Campbell, Review of Vleeskruyer, The Life of St. Chad, in: Journal of English and Germanic Philology 54: 402-404.

Dresher 1980: B. E. Dresher, "The Mercian Second Fronting: A Case of Rule Loss in Old English", in: Linguistic Inquiry 11: 47-73.

Frank and Cameron 1973: R. Frank and A. Cameron, A Plan for the Dictionary of Old English, Toronto.

Fulk 2008: R. D. Fulk, "Anglian Dialect Features in Old English Anonymous Homiletic Literature: A Survey, with Preliminary Findings," in: Studies in the History of the English Language IV: Empirical and Analytical Advances in the Study of English Language Change, ed. S. M. Fitzmaurice and D. Minkova, Berlin, 81-100.

- 2010: R. D. Fulk, "Localizing and Dating Old English Anonymous Prose, and How the Inherent Problems Relate to Anglo-Saxon Legislation," in: English Law before Magna Carta: Felix Liebermann and Die Gesetze der Angelsachsen, ed. S. Jurasinski, L. Oliver and A. Rabin, Leiden, 59-79.

- 2012: R. D. Fulk, "Anglian Features in Late West Saxon Prose," in: Analysing

${ }^{39} \mathrm{An}$ earlier version of this paper was presented to the International Society of Anglo-Saxonists (ISAS, Glasgow, 2015). I am grateful for the feedback received from members of ISAS and the Vereniging van Oudgermanisten. 
Older English, ed. D. Denison, R. Bermúdez-Otero, C. McCully and E. Moore, Cambridge, 63-74.

Fulk and Jurasinski 2012: R. D. Fulk and S. Jurasinski, ed., The Old English Canons of Theodore, Early English Text Society, supplementary series 25, Oxford.

Fulk et al. 2008: R. D. Fulk, R. E. Bjork and J. D. Niles, ed., Klaeber's Beowulf, 4th edn, Toronto.

Garnett 1836: R. Garnett, "English Dialects", in: Quarterly Review 55: 354-387.

Gneuss 1972: H. Gneuss, "The Origin of Standard Old English and Æthelwold's School at Winchester", in: Anglo-Saxon England 1: 63-83.

- 2013: H. Gneuss, "The Old English Language," in: The Cambridge Companion to Old English Literature, ed. M. Godden and M. Lapidge, 2nd edn, Cambridge, 19-49.

Godden 1980: M. Godden, "Flfric's Changing Vocabulary", in: English Studies 61: 206-223.

- 2007: M. Godden, “Did King Alfred Write Anything?", in: Medium AEvum 76: 123.

- 2012: M. Godden, "Stories from the Court of King Alfred," in: Saints and Scholars: New Perspectives on Anglo-Saxon Literature and Culture in Honour of Hugh Magennis, ed. S. McWilliams, Cambridge, 123-140.

- 2013: M. Godden, "Editing Old English Prose and the Challenge of Revision or, Why it is not so Easy to Edit Old English Prose," in: Probable Truth: Editing Medieval Texts from Britain in the Twenty-First Century, ed. V. Gillespie and A. Hudson, Texts and Transitions 5, Turnhout, 2013, 91-110.

Gretsch 2000: M. Gretsch, "The Junius Psalter Gloss: Its Historical and Cultural Context", in: Anglo-Saxon England 29: 85-121.

Gretsch 2013: M. Gretsch, "Literacy and the Uses of the Vernacular," in: The Cambridge Companion to Old English Literature, ed. M. Godden and M. Lapidge, 2nd edn, Cambridge, 273-294.

Halphen 1947: L. Halphen, ed. and trans., Einhard: Vita Karoli, 3rd edn, Paris.

Hebda 2014: A. Hebda, "Phonological Variables," in: The Handbook of Historical Sociolinguistics, ed. J. M. Hernández-Campoy and J. C. Conde-Silvestre, Chichester, 237-252.

Hofstetter 1987: W. Hofstetter, Winchester und der spätaltenglische Sprachgebrauch, Münchener Universitätsschriften, Philosophische Fakultät 14, Munich.

Hogg 1985a: R. M. Hogg, Review of Toon, The Politics of Early Old English Sound Change, in: Journal of Linguistics 21: 245-250.

Hogg 1985b: R. Hogg, "On the Impossibility of Old English Dialectology," in: Luick Revisited, ed. D. Kastovsky and G. Bauer, Tübinger Beiträge zur Linguistik 288, Tübingen, 183-203.

- 2011: R. Hogg, A Grammar of Old English, vol. 1 Phonology, Oxford. 
Irvine 2013: S. Irvine, "English Literature in the Ninth Century," in: The Cambridge History of Early Medieval English Literature, ed. C. A. Lees, Cambridge, 209231.

- 2015: S. Irvine, "The Alfredian Prefaces and Epilogues," in: A Companion to Alfred the Great, ed. N. G. Discenza and P. E. Szarmach, Brill's Companions to the Christian Tradition 58, Leiden, 143-170.

Jayatilaka 2014: R. Jayatilaka, "Werferth," in: The Wiley Blackwell Encyclopedia of Anglo-Saxon England, ed. M. Lapidge et al., 2nd edn, Malden, MA, 498.

Johnson 2015: D. F. Johnson, "Alfredian Apocrypha: The Old English Dialogues and Bede," in: A Companion to Alfred the Great, ed. N. G. Discenza and P. E. Szarmach, Brill's Companions to the Christian Tradition 58, Leiden, 368395.

Jordan 1906: R. Jordan, Eigentümlichkeiten des anglischen Wortschatzes, Anglistische Forschungen 17, Heidelberg.

Keynes 1998: S. Keynes, "King Alfred and the Mercians," in: Kings, Currency and Alliances: History and Coinage of Southern England in the Ninth Century, ed. M. A. S. Blackburn and D. N. Dumville, Studies in Anglo-Saxon History 9, Woodbridge, 1-45.

- 2001: S. Keynes, "Mercia and Wessex in the Ninth Century," in: Mercia: An Anglo-Saxon Kingdom in Europe, ed. J. P. Brown and C. A. Farr, London, 310-328.

- 2014: S. Keynes, "Plegmund", in: The Wiley Blackwell Encyclopedia of AngloSaxon England, ed. M. Lapidge and others, 2nd edn, Malden, 378-379.

- 2015: S. Keynes, "Alfred the Great and the Kingdom of the Anglo-Saxons," in: $A$ Companion to Alfred the Great, ed. N. G. Discenza and P. E. Szarmach, Brill's Companions to the Christian Tradition 58, Leiden, 13-46.

Keynes and Lapidge 1983: S. Keynes, and M. Lapidge, trans., Alfred the Great, Harmondsworth.

Kotzor 1981: G. Kotzor, ed., Das altenglische Martyrologium, Abhandlungen der Bayerischen Akademie der Wissenschaften, phil.-hist. Kl. ns 88, 2 vols., Munich.

Kuhn 1957: S. M. Kuhn, "Some Early Mercian Manuscripts", in: Review of English Studies ns 8: 355-374.

Lapidge 1996: M. Lapidge, "Latin Learning in Ninth-Century England," in: his AngloLatin Literature 600-899, London, item 16.

- 2003: M. Lapidge, "Asser's Reading,", in: Alfred the Great: Papers from the Eleventh-Centenary Conferences, Aldershot, 27-47.

Lass 1994: R. Lass, Old English: A Historical Linguistic Companion, Cambridge.

Liuzza 2001: R. M. Liuzza, "Religious Prose," in: A Companion to Anglo-Saxon Literature, ed. P. Pulsiano and E. Treharne, Blackwell Companions to Literature and Culture 11, Oxford, 233-250. 
Lowe 2001: K. Lowe, "On the Plausibility of Old English Dialectology", in: Folia Linguistica Historica 22: 67-102.

Mitchell 1985: B. Mitchell, Old English Syntax, 2 vols, Oxford.

Mitchell and Robinson 2012: B. Mitchell, and F. C. Robinson, ed., Alfred's Preface to his Translation of Gregory's Pastoral Care, A Guide to Old English, 8th edn, Chichester.

Nielsen 1985: H. F. Nielsen, Old English and the Continental Germanic Languages: A Survey of Morphological and Phonological Interrelations 2nd edn, Innsbruck.

- 1998: H. F. Nielsen, The Continental Backgrounds of English and Its Insular Development until 1154, NOWELE supplement 19, Odense.

ODNB, Oxford Dictionary of National Biography, ed. H. C. G. Matthew and B. Harrison, Oxford, http://www.oxforddnb.com.

$O E D$, Oxford English Dictionary Online, Oxford, http://oed.com.

Pratt 2007: D. Pratt, The Political Thought of King Alfred the Great, Cambridge.

Rauer 2013: C. Rauer, ed., The Old English Martyrology: Edition, Translation and Commentary, Anglo-Saxon Texts 10, Cambridge.

- 2016: C. Rauer, "The Old English Martyrology and Anglo-Saxon Glosses," in: Latinity and Identity in Anglo-Saxon England, ed. R. Stephenson and E. V. Thornbury, Toronto, 73-92.

Roberts 2001: J. Roberts, "Hagiography and Literature: The Case of Guthlac of Crowland," in: Mercia: An Anglo-Saxon Kingdom in Europe, ed. J. P. Brown and C. A. Farr, London, 69-86.

Ross 1969: A. S. C. Ross, "A Connection between Bede and the Anglo-Saxon Gloss to the Lindisfarne Gospels", in: Journal of Theological Studies 20: 482-494.

Rowley 2011: S. M. Rowley, The Old English Version of Bede's Historia ecclesiastica, Anglo-Saxon Studies 16, Cambridge.

- 2015: S. M. Rowley, "The Long Ninth Century and the Prose of King Alfred's Reign", http://www.oxfordhandbooks.com.

Rusche 2016: P. G. Rusche, "The Glosses to the Lindisfarne Gospels and the Benedictine Reform: Was Aldred Trained in the Southumbrian Glossing Tradition?," in: The Old English Gloss to the Lindisfarne Gospels: Language, Author and Context, ed. J. Fernández Cuesta and S. M. Pons-Sanz, Berlin, 61-77.

Rusche forthcoming: P. G. Rusche, "The Old English Martyrology and the Canterbury Aldhelm Scholia".

Schabram 1965: H. Schabram, Superbia: Studien zum altenglischen Wortschatz: Teil I Die dialektale und zeitliche Verbreitung des Wortgutes, Munich.

Schreiber 2003: C. Schreiber, "Dialects in Contact in Ninth-Century England," in: Bookmarks from the Past: Studies in Honour of Helmut Gneuss, ed. L. Kornexl and U. Lenker, Frankfurt a. M., 1-31. 
Seebold 1993: E. Seebold, "Regional gebundene Wörter in Wærferths Übersetzung der Dialoge Gregors des Grossen," in: Anglo-Saxonica: Beiträge zur Vor- und Frühgeschichte der englischen Sprache und zur altenglischen Literatur, Festschrift für Hans Schabram zum 65. Geburtstag, ed. K. R. Grinda and C.-D. Wetzel, Munich, 251-277.

Sisam 1953: C. Sisam, "An Early Fragment of the Old English Martyrology", in: Review of English Studies ns 4: 209-220.

Sisam 1955: C. Sisam, Review of Vleeskruyer, The Life of St. Chad, in: Review of English Studies ns 6: 302-303.

Stanley 1957: E. G. Stanley, Review of Vleeskruyer, The Life of St. Chad, in: English and Germanic Studies 6: 112-118.

Stanton 2002: R. Stanton, The Culture of Translation in Anglo-Saxon England, Cambridge.

Stevenson 1904: W. H. Stevenson, ed., Asser's Life of King Alfred, Oxford.

Toon 1983: T. E. Toon, The Politics of Early Old English Sound Change, Quantitative Analyses of Linguistic Structure 2, New York.

Toon 1992: T. E. Toon, "Old English Dialects," in: The Cambridge History of the English Language, Vol 1: The Beginnings to 1066, Cambridge, 409-451.

Toswell 2014: M. J. Toswell, The Anglo-Saxon Psalter, Medieval Church Studies 10, Turnhout.

Vleeskruyer 1953: R. Vleeskruyer, ed., The Life of St. Chad: An Old English Homily, Amsterdam.

Waite 2013: G. Waite, "The Old English Bede and the Glosses in the Tiberius Bede", in: Parergon 30: 1-49.

- 2014: G. Waite, "Translation Style, Lexical Systems, Dialect Vocabulary, and the Manuscript Transmission of the Old English Bede", in: Medium AEvum 83: 1-48.

Wenisch 1979: F. Wenisch, Spezifisch anglisches Wortgut in den nordhumbrischen Interlinearglossierungen des Lukasevangeliums, Anglistische Forschungen 132, Heidelberg.

Wildhagen 1913: K. Wildhagen, "Studien zum Psalterium Romanum in England und zu seinen Glossierungen," in: Festschrift für Lorenz Morsbach, ed. F. Holthausen and H. Spies, Studien zur englischen Philologie 50, Halle, 417472.

Wilson 1959: R. M. Wilson, "The Provenance of the Vespasian Psalter Gloss: The Linguistic Evidence," in: The Anglo-Saxons: Studies in Some Aspects of their History and Culture Presented to Bruce Dickins, ed. P. Clemoes, London, 292-310.

Woolf 1955: H. B. Woolf, Review of Vleeskruyer, The Life of St. Chad, in: Modern Language Notes 70: 53-55.

Wragg forthcoming: S. Wragg, "The Development of Vernacular Literature in 
Eighth- and Ninth-Century Mercia", DPhil diss., University of Oxford.

Yerkes 1982: D. Yerkes, Syntax and Style in Old English: A Comparison of the Two Versions of Wærferth's Translation of Gregory's Dialogues, Medieval and Renaissance Texts and Studies 5, Binghamton. 